\author{
Andrzej Buszko ${ }^{1}$ \\ University of Warmia and Mazury in Olsztyn
}

\title{
The threats of the shadow economy for public finance in Poland
}

The article is devoted to the treats of the shadow economy for public finance. The close attention was paid to the taxation gap and factors fostering shadow economy. The Pearson coefficient index was used in order to identify the strength of the correlation among chosen variables influencing the taxation gap. Based upon the results it should be stated that factors fostering taxation gap ought to be reduced and more complex action towards reduction of the shadow economy is required to be taken.

Key words: shadow economy, taxation gap, public finance, threats

\section{Introduction}

The shadow economy is regarded to be a distinctiveness of the modern economy. This is due to the main two facts. First shadow economy exists in any country and just varies from the level of it and the category. Secondly the shadow economy affects the legal activity. Almost all societies try to control the level of shadow economy, but it is quite difficult, practically impossible. Despite of many different efforts shadow economy exists and performs moderately vibrant. Schneider estimates the size of the shadow economy between $7.9 \%$ of official Gross Domestic Product (GDP) in the United States and $66.4 \%$ in Georgia. On average, shadow economic activities amount to $15 \%$ of official GDP in Organization for Economic Cooperation and Development (OECD) countries, while the average size in other parts of the world is around 35\% (Schneider, 2010).

From public finance point of view eroding effects on the tax base and social security systems is often emphasized (Torgler, Schneider, Schaltegger, 2010). The shadow economy modifies the set of pledge able fiscal policy contractions. The underlying mechanism associated with this theory is as follows: in an economy characterized with a large informal production, fiscal policy contractions associated with a tax rise can lead to an expansion in the size of the shadow economy and hence limit the amount of government surplus that can be generated resulting from a tax rise (Ceyhun, Burak, 2013).

The roots of the shadow economy are mainly the same. They are connected with:

1) The high level of taxation (Krstić, Schneider, 2015),

2) The complicated and contradicted law system (Ainsworth, 2011),

3) The high level of corruption(Choi, Thum, 2003),

4) The level of organized crime ( Dabla-Norris, Feltenstein, 2003),

5) The culture determinates (Buszko, 2017, Alm, Torgler, 2006),

${ }^{1}$ dr h.c. Head of Finance and Banking Department 
6) The quality of institutional structure (Laruelle, 2008).

As long as taxes exist, some people will choose to hide their actions and refuse to pay their taxes. Addressing this issue demands a profound knowledge of the size of the shadow economy, the extent of tax evasion and the reasons why some people choose illegal unofficial work over a regular job (Reimers, 2014). According to the standard (Allingham-Sandmo) model of tax evasion, the size of the tax burden, along with the probability of detection of tax evasion and the possible sanctions, is a fundamental determinant of tax evasion, as well as of the shadow economy as a basis for tax evasion (Krstić, Schneider, 2015). It could be assumed that the higher level of taxes the higher level of shadow economy appears. This statement supposed to be obviously accepted but under one minor condition. It depends upon the sum of money still kept after taxation by taxpayer and business culture. If the business culture does not accept shadow economy activity the taxpayers are more willingly to fulfill their obligations (Harvey, 1997). Public policy may be influenced toward reducing tax rates if concerns about the underground economy loom large. However, if this is the case, it is also reasonable to consider whether there is a greater benefit to improved enforcement as opposed to reduced taxation (Spiro, 2005). More than forty years have passed since M. Allingham and A. Sandmoback in 1972 published the first more solidly documented theory of tax evasion, where the taxpayer as part of self-assessment selects or declares true income, or perhaps declares a lesser income than the one earned in reality. The taxpayer's choice was dictated by the taxpayer's own perception of probability of tax control and possible fine for under declaring income versus the profit gained by maximizing the amount withheld (Schneider, Raczkowski, Mróz, 2015).

The complicated and contradicted law system supports shadow economy in a very effective way. This is because of the problem of legal performing in such business environment and time as well as cost consuming issue with professional activity. Entrepreneurs face the difficulty with well interpreting law regulations and revenue officers could easily identify not proper functioning of the company. There are many loops in the law so companies try to utilize them as much as they can. But such situation push them to be active in the shadow economy, especially in a long run.

The quality of institutional structure is very important factor fostering shadow economy bustle. One general remark to the mechanism must be underlined. Whenever the institutional structure is weak, the shadow economy appears. This is not only connected with the poor government performance. Market demand is generally fulfilled by two channels. Commonly, one is legal and the second stream is from the shadow economy. Whenever the government cannot make legal activity proper one, efficient and able to meet market demand in empty places, the shadow economy appears. Secondly corrupted government is quite often associated with autocratic regime supports shadow economy substantially and decreasing legal activity (Brubaker, 1996).

Today organised crime and shadow economy are inextricably linked. Organised crime benefits from global criminal networks, solutions developing shadow economy performance. The perpetrators move effortlessly across national borders in these networks, proving they are highly mobile. Poland is particularly important for the participants of organised crime in Europe not only because of its central position and links between West and East, but introducing market oriented economy so such country is very attractive for organized crime and shadow economy committers. Such situation is 
seen in other countries like Germany. The Situation Report on Organised Crime of the Federal Criminal Police Office (BKA) for 2010 recorded 606 cases with 9,632 suspects, more than $60 \%$ of which were of non-German origin. The non- German suspects come from 113 different countries overall. The activities were mainly in the area of drug trafficking and smuggling, followed by economic crime und property crime. The damage in 2009 in Germany was worth around 1.65 billion euros, with the most damage caused by economic crime as well as tax and customs offences. Almost $85 \%$ of the cases had international links (Töttel, Büchler, 2011).

Generally the shadow economy affects legal economy in a depraved way. Such an opinion is widely spread in spite of that there are some academics, researches, even politics state that shadow economy sometimes supports lawful motion. These situations might happen during the slowdown of economy. The surplus of labor force is absorbed by shadow economy. The shadow economy is just the pillow for higher unemployment rate. Secondly people from shadow economy spend at least some money in legal way, so the support budget revenue for example by VAT tax. Schneider based upon his research states that $66 \%$ of earnings in the shadow economy is quickly spent in formal sector. Thirdly the government is not so obliged to assure for such category of people higher social support. But more researches are agree that shadow economy cause the problems for economy, According to the Fraser Institute studies, a growing shadow economy is the sign that the democracy works bad, citizens condemning governments policies through an economic behavior, protesting to the law and regulations, and additionally influenced the usual consumption spending, and mainly those for long term purpose (Florea, Schiop, 2008). More dangerous results of the shadow economy are pointed out by Mara. The shadow economy has a strong social impact and because it is closely linked to a number of phenomena such as corruption, crimes of various types, drugs, mafia type organizations, labor exploitation through a stock black money laundering, human rights violations environmental pollution, etc. Politically, the shadow economy is seen as having negative effects because it emits false signals and induces decision makers as inadequate macroeconomic strategy. As a consequence, any macroeconomic policy on the tax system, unemployment, inflation, savings, social security, productivity and competitiveness is weak (Mara, 2012). Furthermore the shadow economy reduces the quality of life, increases the budget deficit, public debt, domestic and foreign investment, deregulating financial market. For a long run shadow economy may lead to economic chaos and devastate the legal market activity (Katrechka, 2014, Schneider, F., Hametner B., 2007, Misati, 2010, Hindriks J., Keen M., Muthoo A., 1999).

\section{The data and estimation methodology}

The goal of this study is to identify correlation between the level of taxation gap in Poland and factors fostering the shadow economy. The Pearson coefficient index was used. The Pearson correlation coefficient index takes a range of values from +1 to -1 . A value of 0 indicates that there is no association between the variables. A value greater than 0 indicates a positive association; that is, as the value of one variable increases, so does the value of the other variable. A value less than 0 indicates a negative association; that is, as the value of one variable increases, the value of the other variable decreases. The essence test was applied in order to recognize relevance of the results 
(https://statistics.laerd.com/ data of access 2017/09/23). The Statistica software was used to calculate the results. It was assumed that taxation gap is the key feature of the shadow economy from public finance point of view. The higher level of taxation gap the more dangerous situations appears for public finance. The Government can not only handle its statutory duties but capabilities of development actions will be reduced (Ramey G., Ramey V. 1994). Chosen variables are considered informative statistical significance of at least 5\%. The period of investigation 1993-2016.

Following factors fostering shadow economy were accepted:

- Corruption Perception Index (Corr.index),

- The level of fiscal burden - it was calculated by the number of working days sufficient to pay taxes by individual taxpayer (Fiscal burden),

- Index of Economic Freedom. The rule of law, regulatory efficiency, government size and open markets are taken into consideration for calculation ( Index EF),

- Unemployment rate. It was assumed that higher rate of employment promotes activity in the shadow economy frames (Un.rate),

- Fiscal efficiency. Calculated as the sum of spending on fiscal administration as the percentage of the total budget tax revenues (Fiscal eff.).

Table 1. The level of taxation gap and factors fostering shadow economy in Poland 1993-2016

\begin{tabular}{|l|l|l|l|l|l|l|l|l|l|l|l|l|l|l|l|l|l|l|l|l|l|l|l|l|}
\hline Years & 93 & 94 & 95 & 96 & 97 & 98 & 99 & 00 & 01 & 02 & 03 & 04 & 05 & 06 & 07 & 08 & 09 & 10 & 11 & 12 & 13 & 14 & 15 & 16 \\
\hline $\begin{array}{l}\text { Taxation gap } \\
\text { 25bilion PLN }\end{array}$ & 28 & 29 & 30 & 31 & 32 & 33 & 35 & 34 & 37 & 40 & 41 & 40 & 41 & 38 & 34 & 36 & 39 & 42 & 43 & 44 & 43 & 44 & 45 & 47 \\
\hline Corr.index & 44 & 45 & 46 & 45 & 47 & 48 & 47 & 48 & 49 & 51 & 53 & 53 & 54 & 54 & 55 & 56 & 57 & 57 & 58 & 58 & 60 & 61 & 62 & 62 \\
\hline Fiscal burden & 172 & 173 & 171 & 170 & 168 & 167 & 164 & 162 & 165 & 164 & 163 & 162 & 159 & 158 & 156 & 158 & 160 & 163 & 166 & 174 & 172 & 167 & 166 & 161 \\
\hline Index EF & 45 & 46 & 46 & 47 & 50 & 53 & 55 & 56 & 56 & 58 & 59 & 60 & 61 & 64 & 67 & 67 & 68 & 68 & 68 & 69 & 70 & 70 & 69 & 68 \\
\hline Un.rate & 14 & 15 & 16 & 15 & 13 & 10 & 11 & 13 & 15 & 18 & 20 & 21 & 20 & 18 & 15 & 11 & 10 & 12 & 13 & 13 & 14 & 13 & 11 & 10 \\
\hline Fiscal eff. & 1,2 & 1,3 & 1,4 & 1,4 & 1,5 & 1,3 & 1,4 & 1,5 & 1,5 & 1,5 & 1,5 & 1.5 & 1,5 & 1,4 & 1,4 & 1,5 & 1,5 & 1,4 & 1,5 & 1,6 & 1,5 & 1,6 & 1,7 & 1,7 \\
\hline
\end{tabular}

Source: PwC. Luka podatkowa w VAT - jak to zwalczać? Warszawa. Styczeń 2014, Rocznik Statystyczny Rzeczypospolitej Polskiej. GUS. Warszawa. 2017, Doing Business. World Bank. Washington. 2017, Centrum im. Adama Smitha. Gdańsk. Dzień Wolności Podatkowej w Polsce. Warszawa. 2017

The chosen factors from the theoretical point of view are related to the shadow economy and taxation gap. The corruption perception index showing the level of corruption, and the result of it is very important for development and functioning the shadow economy. The higher level of corruption the better situation for shadow economy development. Fiscal burden and fiscal efficiency are closely associated with the first cause of the shadow economy - the higher level of taxation. This issue should be deliberated from the taxpayer point of view. If the taxpayer should work more just to pay the taxes, the more willingly he/she is to start operations in the shadow economy. Unemployment rate is an important factor boosts shadow economy. This is because people without constant paid occupation looking for any job, even in the shadow economy frames. The legal social support is often not sufficient, or even in some countries there is no any care. Index of economic freedom is calculated based upon four main pillars: 
Rule of Law (property rights, government integrity, judicial effectiveness), Government Size (government spending, tax burden, fiscal health),

Regulatory Efficiency (business freedom, labor freedom, monetary freedom), Open Markets (trade freedom, investment freedom, financial freedom).

Each of the freedoms variables within these categories are graded on a scale of 0 to 100 (http://www.heritage.org/index/about date of access 2017/09/24). The higher scoring it means more economic freedom and less space for the shadow economy activity.

\section{Empirical findings and explains}

Since 1993 it can be noticed that taxation gap has been gradually growing up. Just during 2003-2007 the slightly decrease was observed. The shadow economy constitutes ca.30\% of GDP. One should take into account one important issue. Year by year (during investigation period) GDP grew up, and this means that shadow economy raised in real terms as well. Such situation requires reflection and adequate actions.

Figure 1. The level of taxation gap and shadow economy in Poland 1993-2016

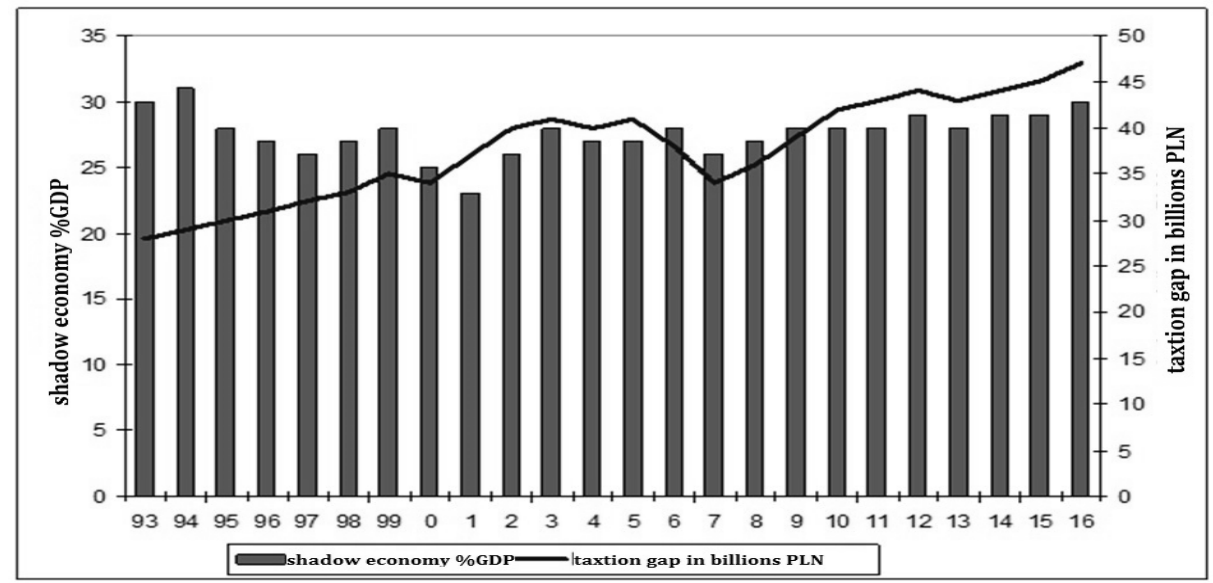

Source: The level of shadow economy was calculated on MIMIC approach, Rocznik Statystyczny Rzeczypospolitej Polskiej GUS. Warszawa. 2017

Referring to the methodological approach in table 2 the coefficient between taxation gap and chosen variables was presented. 
Table 2. The correlation between taxation gap and factors fostering shadow economy

\begin{tabular}{|c|c|c|c|c|c|c|c|}
\hline \multirow[b]{2}{*}{ Zmienna } & \multicolumn{7}{|c|}{$\begin{array}{l}\text { Korelacje (dane } 25-09-2017) \\
\text { Oznaczone wsp. korelacji sa istotne z p <,05000 } \\
\mathrm{N}=24 \text { (Braki danych usuwano przypadkami) }\end{array}$} \\
\hline & Średn Odch. & Taxation gap bil & Corr.ins & Fiscal bu & Index & Un.rat & Fiscal \\
\hline Taxation gap billi & $37,7 ! \quad 5,495$ & 1,000 & 0,906 & $-0,26 \approx$ & 0,859 & $-0,045$ & 0,806 \\
\hline Corr.index & $52,9 \cdot 5,792$ & 0,906 & 1,000 & $-0,322$ & 0,957 & $-0,217$ & 0,746 \\
\hline Fiscal burden & $164,9 \quad 5,149$ & $-0,26 ?$ & $-0,322$ & 1,000 & $-0,44 \epsilon$ & $-0,105$ & $-0,20 \varepsilon$ \\
\hline Index EF & $60,01 \quad 8,672$ & 0,859 & 0,957 & $-0,44 \epsilon$ & 1,000 & $-0,21 \varepsilon$ & 0,661 \\
\hline Un.rate & $14,21 \quad 3,256$ & $-0,045$ & $-0,217$ & $-0,105$ & $-0,21 \varepsilon$ & 1,000 & $-0,132$ \\
\hline Fiscal eff. & $1,47 \quad 0,116$ & 0,806 & 0,746 & $-0,20 \varepsilon$ & 0,661 & $-0,132$ & 1,000 \\
\hline
\end{tabular}

Source: calculation was done based upon the data presented in table 1

The results are awesome. There is a very strong correlation (coefficient index 0,9062 ) between taxation gap and corruption perception index. There is a strong correlation between taxation gap and the index of economic freedom $(0,8593)$, as well as between taxation gap and fiscal efficiency $(0,8064)$. The other achieved results are not important from statistical point of view.

The closer attention supposed to be put on corruption perception index in Poland. Generally the situation with corruption in Poland has been improving. The level of it has been going down. Even though the structure of corruption was changed, Poland is seen as relatively clean country (Transparency International, 2016). However such situation may come to the assumption that taxation gap in Poland is not influenced by corruption. Similar situation is connected with the index of economic freedom. Economic freedom commonly has been getting better. The introduced market oriented reforms made relatively not bad business environment. From the other hand the structure of the index of economic freedom is based on the wide scope of different features. In Polish situation justice system and law regulations supposed to be separately taken into account as the factors fostering taxation gap and parallel shadow economy. This is mainly because of the already highlighted problem of VAT frauds. Value added tax (VAT) generates significant public revenue (more than one fifth of world total tax revenue, including social contributions) and has been introduced in about 140 countries. In Poland it is the main source of revenue and plays an important role in ensuring public finance stability (Gut, 2015). It is estimated that the budget losses of VAT frauds (starting from 1990) amounted to 250 billion PLN (Gazeta Prawna. 21.09.2017). Such spectacles are very devastating for public finance stability. Just very clear situation is connected with fiscal efficiency. It is on a low level, comparing it to west European countries. In Poland it is on the level increasing 1,5\% but in Norway 0,55\% (Wojciechowski, 2015). The higher level of taxation gap is strictly connected with fiscal efficiency in Poland. The puzzling thing is that there is no association with taxation gap and unemployment rate. Such situation may be explained by a good economic situation and decreasing rate of unemployment. And additionally to that Schneider results of his research may be applied. Workers from shadow economy spend their money in legal economy, so they support budget revenue. 


\section{Conclusions}

The study shows there is the problem in Poland with taxation gap and the shadow economy. Both economic categories have been influencing the public finance and reducing capabilities of government development actions. For a longer run the financial gap in the frames of the shadow economy can even jeopardize the financial security. The results of the study display that the more studies in this field are required. Especially more studies should be taken on the structure of the shadow economy and the roots of the taxation gap. In this circumstance it would be necessary to pay more attention to financial frauds for example VAT. VAT frauds should be explored from relatively low level of fiscal administration efficiency and in spite of relatively good scoring economic freedom.

\section{References}

Alm J., Torgler B. Culture differences and tax morale in the United States and in Europe. Journal of Economic Psychology, Vol. 27 No. 2, 2006

Ainsworth R.T. VAT fraud as a policy stimulus - is the US watching? VAT withholding vat and the Mittler Model, BU Law Working Paper 11-08, February, 2011

Brubaker R. Nationalism Reframed: Nationhood and the National Question in the New Europe. Cambridge University Press, Cambridge. 1996

Buszko A. Cultural Implications for the Shadow Economy. Engineering Economics. 2017 (under printing process)

Centrum im. Adama Smitha. Gdańsk. Dzień Wolności Podatkowej w Polsce. Warszawa. 2017

Ceyhun R., Burak R.U. Public debt, sovereign default risk and shadow economy. Journal of Financial Stability No 9, 2013

Choi P.J., Thum M. The dynamics of corruption with the ratchet effect", Journal of

Public Economics, Vol. 87 Nos 3/4, 2003

Dabla-Norris E., Feltenstein A. An analysis of the underground economy and its economic consequences. Working Paper 23/03, Washington, DC, International Monetary Fund. 2003

Doing Business. World Bank. Washington. 2017

Florea A., Schiop C. Are there any positive consequences of underground economy? Fascicle of Management and Technological Engineering, Volume VII (XVII). 2008

Gazeta Prawna. 21.09.2017

Gut, P. Experimental Evaluation of the Efficiency of the Third Party Joint and Several Liability in the Polish VAT System. European Journal of Economic Studies, Vol.(12), Is. 22015

Harvey F. National cultural differences in theory and practice Evaluating Hofstede's national cultural framework. Information Technology \& People, Vol. 10 No. 2, 1997

Hindriks J., Keen M., Muthoo A. Corruption, extortion and evasion. Journal of Public Economics, 74(3), 1999 Katrechka, A. The effect of the shadow economy on social development. A comparative study on advanced and least developed countries. University of Gothenburg. 2014

Krstić G., Schneider F. Formalizing the Shadow Economy in Serbia. Policy Measures and Growth Effects. Springer Cham Heidelberg New York Dordrecht London. 2015

Laruelle M. The concept of ethnogenesis in Central Asia: political context and institutional mediators (194050). Kritika: Explorations in Russian and Eurasian History 9 (1), 2008

Mara E.R. Causes and Consequences of Underground Economy. MPRA Paper No. 36438, 2012

Misati R. N. The role of the informal sector in investment in Sub-Saharan Africa. International Entrepreneurship and Management Journal, 6(2) 2010

PwC. Luka podatkowa w VAT - jak to zwalczać? Warszawa. Styczeń, 2014

Ramey G., Ramey V. Cross-country evidence on the link between volatility and growth", Working Paper 4959, Cambridge, MA, NBER. 1994

Reimers, O. CESifo DICE Report 4/2014 (December)

Rocznik Statystyczny Rzeczypospolitej Polskiej. GUS. Warszawa. 2017 
Schneider F. The influence of public institutions on the shadow economy: an empirical investigation for OECD countries, Review of Law and Economics 6, 2010

Schneider, F., Hametner B. The shadow economy in Colombia: size and effects on economic growth (No. 0703). Working Paper, Department of Economics, Johannes Kepler University of Linz, 2007

Schneider F., Raczkowski K., Mróz B. Shadow economy and tax evasion in the EU. Journal of Money Laundering Control, Vol. 18 Iss 1, 2015

Spiro, P.S. Tax Policy and the Underground Economy [in:] Schneider F., Bajada, Ch. Size, Causes and Consequences of the Underground Economy. Ashgate Publishing, Aldershot, England 2005

Torgler B., Schneider F., Schaltegger C. Local autonomy, tax morale, and the shadow economy, Public Choice 144,2010

Töttel U., Büchler H. Research Conferences on Organised Crime at the Bundeskriminalamt in Germany 2008 2010. Wolters Kluwer Deutschland GmbH, Köln. 2011

Transparency International. Corruption Perception Index 2015. London. 2016

Wojciechowski, T. Podatki w Polsce, jesteśmy europejskim liderem w kosztach ściagalności danin. Gazeta Prawna. 5 marzec, 2015

https://statistics.laerd.com/ data of access 2017/09/23

http://www.heritage.org/index/about date of access 2017/09/24

\section{Informacje o autorze:}

dr hab. Andrzej Buszko, prof. UWM

Uniwersytet Warmińsko-Mazurski w Olsztynie

Wydział Nauk Ekonomicznych, Katedra Finansów i Bankowości

ul. M. Oczapowskiego 4

e-mail: buszko@uwm.edu.pl 